\title{
PKM INOVASI PEMBERDAYAAN MASYARAKAT DALAM PERENCANAAN PEMBANGUNAN DESA PASIR PUTIH KABUPATEN HALMAHERA SELATAN
}

\author{
Marno Wance ${ }^{1)}$, Pahrul Idham Kaliky'), Ummu Syahidah²) \\ 1)Program Studi IImu Pemerintahan, FISIP, Universitas Pattimura, Maluku, Indonesia \\ 2)Program Studi Pendidikan Bahasa Inggris, FIP, Universitas Muhammadiyah Maluku Utara, Maluku, Indonesia \\ Corresponding author: Marno Wance \\ E-mail : marno.wance@fisip.unpatti.ac.id
}

Diterima 1 Februari 2020, Disetujui 5 April 2020

\begin{abstract}
ABSTRAK
PKM Inovasi pemberdayaan masyarakat desa Pasir Putih, Kabupaten Halmahera Selatan dilaksanakan dalam bentuk pelatihan dan pendampingan pemberdayaan masyarakat. Hasil observasi awal menemukan permasalahan yaitu pengembangan pembangunan desa Pasir Putih masih dilakukan dengan cara yang sangat tradisional baik dalam melakukan aktivitas pertanian, penangkapan ikan, maupun cara pengembangan ekonomi kreatif. Oleh karena itu, sangat diperlukan adanya inovasi pembangunan pemberdayaan masyarakat yang berbasis pada kolaborasi masyarakat dan pemerintah desa sehingga dapat meningkatkan kreaktivitas dan dapat mengelola kekayaan alam di desa dengan maksimal. Manfaat PKM pemberdayaan ini adalah untuk menambah pengetahuan masyarakat dan pemerintah desa tentang inovasi pemberdayaan masyarakat, khususnya pada pembangunan pemerintah desa pesisir. Secara praktis pengabdian ini bisa menghasilkan bahan kajian untuk berbagai pihak yang berkepentingan yang memerlukan analisis tata kelola pemberdayaan di desa pesisir seperti di desa Pasir Putih, Kabupaten Halmahera Selatan. Di samping itu, pengabdian ini dilakukan juga untuk melihat keterlibatan dari pemerintah desa dan masyarakat, khususnya para pemuda dalam mengimplementasikan inovasi pemberdayaan masyarakat yang mampu mendorong adanya peningkatan dalam pembangunan moral masyarakat dan pembangunan fisik desa yang sesuai dengan yang direncanakan.
\end{abstract}

Kata kunci: pemberdayaan; pembangunan desa; pemerintah desa.

\begin{abstract}
PKM Innovation for community empowerment in Pasir Putih village, South Halmahera Regency was carried out in the form of training and community empowerment assistance. The results of preliminary observations found that the development of the Pasir Putih village was still carried out in a very traditional way such as carrying out agricultural activities, fishing, and development of creative economy. Therefore, innovation in community empowerment development based on community collaboration and village government is needed to improve creativity and manage natural resources in the village to the fullest. The benefit of this empowerment PKM is to increase community and village government knowledge about community empowerment innovation, especially in the development of coastal village government. Practically this activity can produce study material for various stakeholders who need an analysis of governance empowerment in coastal villages such as in Pasir Putih village, South Halmahera Regency. In addition, this activity is also carried out to see the involvement of the village government and the community, especially young people in implementing innovative community empowerment that is able to encourage an increase in community moral development and physical development of the village as planned.
\end{abstract}

Keywords: empowerment; village development; village government.

\section{PENDAHULUAN}

Desa Pasir Putih sebagai lokasi pengabdian menjadi hal yang sangat memberi kebahagiaan bagi pemerintah Desa. Desa Pasir Putih yang masih minim pengetahuan tentang tata pengelolaan organisasi pemerintahan yang baik. Hadirnya inovasi pembangunan pemerintah desa sedikit banyaknya telah menunjang tata kelola organisasi yang baik bagi pemerintah Desa Pasir Putih.

Desa Pasir Putih yang merupakan salah satu dari 6 Desa yang berada di kayoa Selatan. Luas wilayah Desa Pasir Putih secara keseluruhan adalah seluas $86 \mathrm{Ha}$. Desa Pasir Putih berada di ketinggian antara 0 meter sampai 2 meter di atas permukaan laut. Desa 
Pasir Putih secara topografi merupakan dataran pantai dan dataran rendah. Wilayah Pasir Putih yang beriklim tropik basah memiliki curah hujan sebesar 200-300 mm/tahun. DesaPasir Putih memiliki intensitas curah hujan sedang sehingga dapat mendukung kegiatan masyarakat dalam bidang pertanian dengan catatan di atur secara baik. Potensi dibidang kelautan, pertanian, dan industri kecil merupakan potensi unggulan yang terdapat di Desa Pasir Putih. Komoditas hasil tangkapan laut sangat menjanjikan jika dikelola dengan baik. Dari dua musim yang berada di Desa Pasir Putih yaitu musim panas dan musim hujan sehingga masih banyak potensi yang perlu di gali dan dikembangkan demin kemajuan Desa ini. musim hujan biasanya terjadi di bulan desember hingga februari sedang musim panas terjadi di bulan april hingga bulan agustus.

Aspek sumber daya alam yang masih bisa di gali dan dikembangkan demi kemajuan Desa sebagai berikut :

a) Lahan pertanian yang masih bisa ditingkatkan produktifitasnya apabila di tunjang dengan pengelolaan yang menggunakan teknologi modern.

b) Wilayah perkampungan yang sangat potensial untuk beternak, namun belum banyak warga masyarakat yang menyentuh.

c) Swering yang berada di area perkampungan belum di manfaatkan untuk penanaman pohon mangrove

d) Lahan pekarangan rumah yang tidak dipergunakan secara baik.

Potensi sumber daya manusia yang ada di DesaPasir Putih masih perlu dikembangkan, berbagai tenaga terampil di bidang perikanan dan pertanian merupakan modal bagi pembangunan ekonomi Desa dan masyarakat. Namun potensi ini belum bisa di maksimalkan oleh masyarakat Desa. Penduduk DesaPasir Putih yang dari tahun sebelumnya berjumlah 395 jiwa dan sekarang di tahun 2018 menurun di angka 276 yang merupakan masyarakat yang masih percaya akan potensi Desa hingga masih bertahan hidup di Desa ini. penduduk yang masih bertahan jika di bekali pengetahuan yang baik dan di akomodir secara tersistematis akan membawa dampak yang baik bagi perkembangan Desa ini.

$$
\text { Seiring berjalannya waktu, }
$$
perkembangan juga semakin pesat terjadi dalam setiap daerah. Dan tak ada tempat yang tak menghendaki perkembangan. Dibalik berkembangnya suatu daerah akan ada masalah-masalah yang di hadapi, baik yang berbentuk fisik maupun non-fisik. Adapun masalah-masalah yang menjadi tolak ukur kami dalam inovasi pemberdayaan di Desa ini sebagai berikut :

Tabel 1. Permasalahan Desa

\begin{tabular}{|l|l|l|}
\hline No & \multicolumn{1}{|c|}{ Permasalahan Desa } & $\begin{array}{c}\text { Ketera } \\
\text { ngan }\end{array}$ \\
\hline 1 & $\begin{array}{l}\text { Sarana dan pra saran polindes } \\
\text { yang belum memadai }\end{array}$ & \\
\hline 2 & $\begin{array}{l}\text { Tempat pelayanan posyandu } \\
\text { yang belum representataif }\end{array}$ & \\
\hline 3 & $\begin{array}{l}\text { Belum optimalnya penyuluhan } \\
\text { kesehatan bagi warga } \\
\text { masayarakat }\end{array}$ & \\
\hline 4 & $\begin{array}{l}\text { Tenaga kesehatan yang masih } \\
\text { kurang }\end{array}$ & \\
\hline 5 & $\begin{array}{l}\text { BUMDes yang belum berjalan } \\
\text { secara maksimal }\end{array}$ & \\
\hline 6 & $\begin{array}{l}\text { Pelatihan keterampilan bagi } \\
\text { remaja usia produktif yang masih } \\
\text { kurang }\end{array}$ & \\
\hline 7 & $\begin{array}{l}\text { Sarana dan prasarana masjid } \\
\text { yang masih butuh perhatian }\end{array}$ & \\
\hline 8 & $\begin{array}{l}\text { Peralatan modern yang belum } \\
\text { ada dalam pengelolaan } \\
\text { pertanian }\end{array}$ & \\
\hline 9 & $\begin{array}{l}\text { Penyuluhan pembuatan pupuk } \\
\text { organik yang belum pernah } \\
\text { dilakukan }\end{array}$ & \\
\hline 10 & $\begin{array}{l}\text { Abrasi pantai yang masih terjadi } \\
\text { Masih ada beberapa warga yang } \\
\text { belum memiliki jaminan } \\
\text { kesehatan }\end{array}$ & \\
\hline
\end{tabular}

Sumber: Profil Pemerintah Desa Tahun 2016

Dari tabel 1 tersebut di atas menjadi pokok perhatian di Desa Pasir Putih. Uraian di atas belum mencakup semua yang menjadi masalah yang ada di Desa Pasir Putih. Uraian diatas adalah penelitian, pengamatan, serta hasil diskusi kami bersama warga masyarakat Desa Pasir Putih. Tidak menutup kemungkinan masih ada masalah lain yang belum tersebutkan di atas. Terlebih karena waktu 2 bulan belumlah cukup untuk mengetahui semua masalah yang terjadi di Desa Pasir Putih. Dan masalah akan terus ada seiring berjalannya waktu. Sebagai warga masyarakat harus menyikapinya dengan senantiasa membuka solusi demi kemajuan Desa.

Sehingga sangat menarik untuk melakukan pengabdian ada aspek "Inovasi Pemberdayaan Masyarakat dalam Pembangunan Pemerintah Desa Pesisir". Peneliti disini ingin mengungkap Inovasi pembangunan pemerintah desa serta budaya pembangunan pada masyarakat desa pesisir.

\section{Manfaat Pengabdian Masyarakat}

Adapun manfaat pengabdian atas survei potensi Desa Pasir Putih adalah sebagai berikut 
1. Mengembangkan kreatifitas masyarakat desa pasir putih dengan melakukan pengabdian selama di desa

2. Mengembangkan perilaku inovasi dalam melakukan persesuaian antara program pemerintah desa dan masyarakat serta peneliti pada Desa Pasir Putih

3. Memahami kultur budaya masyarakat setempat serta mengenal dan menyesuaikan tentang kehidupan masyarakat Desa Pasir Putih.

4. Membantu proses pendidikan dan pembelajaran pada siswa dan siswi.

5. Melakukan pendataan serta pemetaan administrasi pemerintah Desa

\section{METODE}

Jenis Penelitian ini menggunakan pendekatan penelitian Deskriptif kualitatif yaitu ada beberapa definisi mengenai pendekatan ini. (Lexy, 2011). menjelaskan bahwa metodologi kualitatif sebagai prosedur penelitian yang menghasilkan data deskriptif berupa kata-kata tertulis atau lisan dari orang-orang dan perilaku yang dapat di amati. di mana metode yang di gunakan menekankan pada proses penelusuran data/informasi hingga di rasakan telah cukup di gunakan untuk membuat suatu interpretasi. Tipe penelitian deskriptif yaitu bertujuan untuk mendeskripsikan secara terperinci mengenai fenomena-fenomena sosial tertentu yang berkenaan dengan masalah dan untuk diteliti. Selain itu, untuk melakukan analisis data peneliti menggunakan SPSS untuk melakukan analisis tentang potensi kemampuan pada desa pasisir putih di Kabupaten Halmahera Selatan

\section{Jenis dan Sumber Data}

Jenis data yang digunakan dalam penelitian ini adalah:

1. Data primer, adalah data yang diperoleh di lapangan dengan pengamatan secara langsung dengan melakukan survei serta pendataan penduduk

2. Data sekunder, adalah data yang diperoleh melalui studi kepustakaan, yaitu dengan menelaah literatur, artikel, serta analisis kondisi masyarakat Desa Pasir Putih.

Sumber data dalam penelitian ini adalah:

a. Penelitian Pustaka (library research), yaitu menelaah berbagai buku kepustakaan, koran dan karya ilmiah yang ada hubungannya dengan objek penelitian.

b. Penelitian survei lapangan yaitu pengumpulan data dengan mengamati secara sistematis terhadap fenomena-

fenomena yang diselidiki dan
melakukan
masyarakat.

\section{HASIL DAN PEMBAHASAN \\ Konsep Pemberdayaan Masyarakat}

Pemberdayaan atau pemberkuasaan (empowerment), secara konseptual berasal dari kata "power" (kekuasaan atau keberdayaan). Karenanya, ide utama pemberdayaan bersentuhan dengan konsep mengenai kekuasaan. Kekuasaan seringkali dikaitkan dengan kemampuan kita untuk membuat orang lain melakukan apa yang kita inginkan, terlepas dari keinginan dan minat mereka. IImu sosial tradisional menekankan bahwa kekuasaan berkaitan dengan pengaruh dan kontrol. Pengertian ini mengasumsikan bahwa kekuasaan sebagai sesuatu yang tidak berubah atau tidak dapat dirubah. (Suharto, 2006).

Pemberdayaan menunjuk pada kemampuan orang khususnya kelompok rentan dan lemah dan tidak memiliki akses sehingga mereka memiliki kekuatan atau kemampuan dalam berbagai dimensi kehidupannya. Suharto (2006) melihat dimensi-dimensi tersebut adalah (a) memenuhi kebutuhan bukan saja bebas mengemukakan pendapat, melainkan bebas dari kelaparan, bebas dari kebodohan, bebas dari kesakitan (b) menyangkut sumber-sumber produktif yang memungkinkan mereka dapat meningkatkan pendapatanya dan memperoleh barang-barang dan jasa-jasa yang mereka perlukan, dan (c) berpartisipasi dalam proses pembangunan dan keputusan-keputusan yang mempengaruhi mereka.

1. Pemberdayaan bertujuan untuk meningkatkan kekuasaan orang-orang yang lemah atau tidak beruntung (Ife, 1995).

2. Pemberdayaan menunjuk pada usaha pengalokasian kembali kekuasaan melalui pengubahan struktur sosial (Swift dan Levin, 1987).

3. Pemberdayaan adalah suatu cara dengan mana rakyat, organisasi, dan komunitas diarahkan agar mampu menguasai (atau berkuasa atas) kehidupannya (Rappaport, 1984).

4. Pemberdayaan adalah sebuah proses dengan mana orang menjadi cukup kuat untuk berpartisipasi dalam, berbagi pengontrolan atas, dan mempengaruhi terhadap, kejadiankejadian serta lembaga-lembaga yang mempengaruhi

kehidupannya...Pemberdayaan

menekankan bahwa orang memperoleh keterampilan, pengetahuan, dan kekuasaan yang 
cukup untuk mempengaruhi kehidupannya dan kehidupan orang lain yang menjadi perhatiannya (Parsons, et al., 1994).

5. Pemberdayaan menunjuk pada kemampuan orang, khususnya kelompok rentan dan lemah, untuk (a) memiliki akses terhadap sumbersumber produktif yang memungkinkan mereka dapat meningkatkan pendapatannya dan memperoleh barang-barang dan jasa-jasa yang mereka perlukan; dan (b) berpartisipasi dalam proses pembangunan dan keputusan-keputusan yang mempengaruhi mereka.

Definisi pemberdayaan yang dikemukakan para pakar sangat beragam dan kontekstual. Akan tetapi dari berbagai definisi tersebut, dapat ditarik suatu benang merah bahwa pemberdayaan masyarakat merupakan upaya untuk memampukan dan memandirikan masyarakat. Atau dengan kata lain adalah bagaimana menolong masyarakat untuk mampu menolong dirinya sendiri. Sumber : Edi Suharto, 2004.

Sedangkan Hasil penelitian yang dilakukan oleh Suhu, Wance (2019) bahwa Peneliti memberikan saran kepada pemerintah Kabupaten Halmahera Selatan untuk dapat melakukan intervensi kepada nelayan dalam memberikan perlengkapan alat tangkap yang memadai serta melakukan sosialisasi kepada para nelayan tentang keselamatan pelayaran laut. Diharapkan dengan bantuan swasta kepada nelayan perlu ditingkatkan dalam bentuk pemberdayaan perorangan dan kelompok, dan pelatihan penggunaan teknologi penangkapan. Dengan dampak positif yang ditimbulkan dari pemberdayaan diharapkan dapat dipergunakan untuk keperluan yang diutamakan dan bernilai produktif.(Bakri La Suhu, Marno Wance,Rasid Pora, Abdulah Kaunar, 2019).

Berbeda temuan dari Molle, dkk (2015) bahwa kepada pemerintah desa untuk memberikan perhatian dengan mensosialisasikan program kepada masyarakat untuk menghimbau atau mengundang masyarakat untuk berpatisipasidalam tahap perencanaan. Karena dengan adanya sosialisasi yang dilaksanakan oleh pemerintah desa maka tentunya masyarakat akan tahu manfaat keterlibatan dalam penyusunan program.(Molle et al., 2015).

\section{Indikator Pemberdayaan}

Pendekatan utama dalam konsep pemberdayaan adalah bahwa masyarakat tidak dijadikan objek dari berbagai proyek pembangunan, tetapi merupakan subjek dari upaya pembangunannya sendiri. Berdasarkan konsep demikian, maka pemberdayaan masyarakat harus mengikuti pendekatan sebagai berikut (Sumodiningrat, Gunawan, 2002) ;

pertama, upaya itu harus terarah. Ini yang secara populer disebut pemihakan.Upaya ini ditujukan langsung kepada yang memerlukan, dengan program yang dirancang untuk mengatasi masalahnya dan sesuai kebutuhannya.

Kedua, program ini harus langsung mengikutsertakan atau bahkan dilaksanakan oleh masyarakat yang menjadi sasaran. Mengikutsertakan masyarakat yang akan dibantu mempunyai beberapa tujuan, yakni agar bantuan tersebut efektif karena sesuai dengan kehendakdan mengenali kemampuan serta kebutuhan mereka. Selain itu, sekaligus meningkatkan kemampuan masyarakat dengan pengalaman dalam merancang, melaksanakan, mengelola, dan mempertanggungjawabkan upaya peningkatan diri dan ekonominya.

Ketiga, menggunakan pendekatan kelompok, karena secara sendiri-sendiri masyarakat miskin sulit dapat memecahkan masalahmasalah yang dihadapinya. Juga lingkup bantuan menjadi terlalu luas jika penanganannya dilakukan secara individu. Pendekatan kelompok ini paling efektif dan dilihat dari penggunaan sumber daya juga lebih efisien. Schuler, Hashemi dan Riley mengembangkan beberapa indikator pemberdayaan, yang mereka sebut sebagai empowerment index atau indeks pemberdayaan. (Hadi, 2015)

a) Kebebasan mobilitas: kemampuan individu untuk pergi ke luar rumah atau wilayah tempat tinggalnya, seperti ke pasar, fasilitas medis, bioskop, rumah ibadah, ke rumah tetangga. Tingkat mobilitas ini dianggap tinggi jika individu mampu pergi sendirian.

b) Kemampuan membeli komoditas 'kecil': kemampuan individu untuk membeli barang-barang kebutuhan keluarga seharihari (beras, minyak tanah, minyak goreng, bumbu); kebutuhan dirinya (minyak rambut, sabun mandi, rokok, bedak, sampo). Individu dianggap mampu melakukan kegiatan ini terutama jika ia dapat membuat keputusan sendiri tanpa meminta ijin pasangannya; terlebih jika ia dapat membeli barang-barang tersebut dengan menggunakan uangnya sendiri.

c) Kemampuan membeli komoditas 'besar': kemampuan individu untuk membeli barang-barang sekunder atau tersier, seperti lemari pakaian, TV, radio, koran, 
majalah, pakaian keluarga. Seperti halnya indikator di atas, poin tinggi diberikan terhadap individu yang dapat membuat keputusan sendiri tanpa meminta ijin pasangannya; terlebih jika ia dapat membeli barang-barang tersebut dengan menggunakan uangnya sendiri.

d) Terlibat dalam pembuatan keputusankeputuan rumah tangga: mampu membuat keputusan secara sendiri mapun bersama suami/istri mengenai keputusankeputusan keluarga, misalnya mengenai renovasi rumah, pembelian kambing untuk diternak, memperoleh kredit usaha.

e) Kebebasan relatif dari dominasi keluarga: responden ditanya mengenai apakah dalam satu tahun terakhir ada seseorang (suami, istri, anak-anak, mertua) yang mengambil uang, tanah, perhiasan dari dia tanpa ijinnya; yang melarang mempunyai anak; atau melarang bekerja di luar rumah.

f) Kesadaran hukum dan politik: mengetahui nama salah seorang pegawai pemerintah desa/kelurahan; seorang anggota DPRD setempat; nama presiden; mengetahui pentingnya memiliki surat nikah dan hukum-hukum waris.

g) Keterlibatan dalam kampanye dan protesprotes: seseorang dianggap 'berdaya' jika ia pernah terlibat dalam kampanye atau bersama orang lain melakukan protes, misalnya, terhadap suami yang memukul istri; istri yang mengabaikan suami dan keluarganya; gaji yang tidak adil; penyalahgunaan bantuan sosial; atau penyalahgunaan kekuasaan polisi dan pegawai pemerintah.

h) Jaminan ekonomi dan kontribusi terhadap keluarga: memiliki rumah, tanah, asset produktif, tabungan. Seseorang dianggap memiliki poin tinggi jika ia memiliki aspekaspek tersebut secara sendiri atau terpisah dari pasangannya. (Hadi, 2015)

Pemberdayaan atau pembangunan di daerah seharusnya di upayakan menjadi skala proritas penting dalam pembangunan kita di masa sekarang ini dan maupun di masa yang akan datang, upaya demikian sekurang-kurang perlu memperhatikan tiga hal penting antara lain, (a) bentuk kontri- busi riil di daerah yang diharapkan oleh pemerintah pusat dalam proses pemba- ngunan dasar, (b) aspirasi masyarakat dae- rah itu sendiri terutama yang terefleksi pada prioritas program-program pembangunan daerah, dan (c) keterkaitan antardaerah dalam tata perekonomian dan politik lokal. (Miradj \& Sumarno, 2014).

\section{Kondisi Sosial Masyarakat}

Dalam sistem pemerintahan di Indonesia pemerintah desa merupakan unit pemerintahan terendah yang berhubungan langsung dengan kehidupan masyarakat. Kepala desa merupakan seorang yang telah dipilih secara demokrasi melalui pemilihan langsung oleh masyarakat setempat yang telah memiliki hak suara berdasarkan peraturan yang ada. Kepala desa memiliki wewenang yang besar dalam menyelenggarakan pemerintahan desa. Dalam pelaksanaannya, seorang kepala desa dibantu oleh beberapa perangkat desa seperti kepala urusan, kepala desa, serta BPD mereka saling menjalin relasi dengan satu sama lain.

Secara topografi, Desa Pasir Putih dapat dibagi dalam 2 wilayah yaitu wilayah pantai di bagian permukaan laut, dan wilayah daratan rendah di bagian perkampunngan dan sebagian perkebunan. Luas lahan yang ada terbagi dalam beberapa peruntukan seperti untuk fasilitas umum, pemukiman, pertanian, kesehatan, pendidikan, kegiatan ekonomi, dan lainnya, dengan panjang pantai sepanjang 500 $\mathrm{M}$ dan daratan seluas $400 \mathrm{Ha}$, yang terdiri dari :

- Peruntukan pertanian : $250 \mathrm{Ha}$

- Peruntukan Pemukiman: $50 \mathrm{Ha}$

- Peruntukan fasilitas umum dan ekonomi lain : $100 \mathrm{Ha}$

Secara administrasi wilayah DesaPasir Putih terdiri dari 2 RT dengan kondisi topografi demikian, Desa Pasir Putih memiliki variasi ketinggian antara $0 \mathrm{M}$ sampai dengan $2 \mathrm{M}$ dari permukaan laut. Daerah wilayah RT 01 adalah daratan terendah sebaliknya di wilayah RT 02 adalah wilayah tertinggi.

Berdasrakan pada pendataan pada tahun 2018 jumlah penduduk yang tercatat berjumlah 271 jiwa, data jumlah penduduk ini menurun berdasarkan pada data administrasi pemerintah Desa yaitu berjumlah 381 jiwa pada tahun 2013, meningkat menjadi 386 jiwa di tahun 2014 dan pada tahun 2015 menurun menjadi 391 jiwa dan pada akhir tahun 2016 jumlah penduduk Pasir Putih meningkat menjadi 395 jiwa.

Adapun rincian penduduk berdasarkan jenis kelamin secara rinci dapat dilihat pada tabel di bawah ini :

Tabel 2. Jumlah penduduk Desa Pasir Putih berdasarkan jenis kelamin

\begin{tabular}{|l|l|c|}
\hline \multicolumn{3}{|c|}{ Jenis Kelamin } \\
\hline Jenis Kelamin & \multicolumn{1}{|c|}{ Frekuensi } & $\%$ \\
\hline Laki-Laki & 141 & 51.1 \\
\hline Perempuan & 135 & 48.9 \\
\hline Total & 276 & 100 \\
\hline \multicolumn{2}{|c|}{ (Sumber : Data Primer KKS UMMU }
\end{tabular}

Tahun 2018) 
Seperti terlihat pada tabel 2 diatas, menunjukkan bahwa jumlah penduduk pada tahun 2018 antara laki-laki dan perempuan dengan persentase $51,1 \%$ jumlah laki-laki sedangkan 48,9\% jumlah perempuan. Sehingga persentase jumlah jenis kelamin di DesaPasir Putih perbandingan antara laki-laki dan perempuan masih seimbang.

\section{Sumber Daya Alam}

Menurut Undang-undang Nomor 6 Tahun 2014, Kepala Desa sebagai penyelenggaraan urusan Pemerintahan Desa yang menjadi kewenangan adalah urusan Pemerintahan Desa yang sudah ada berdasarkan asal-usul Desa. Urusan Pemerintah Desa yang secara langsung dapat meningkatkan pelayanan, pembangunan dan pemberdayaan masyarakat serta tugas pembantuan dari Pemerintah propinsi, dan pemerintah Kabupaten/Kota.

Desa Pasir Putih merupakan salah satu dari 6 Desa yang berada di kecamatan kayoa Selatan. Luas wilayah Desa Pasir Putih secara keseluruhan adalah seluas $86 \mathrm{Ha}$. DesaPasir Putih berada di ketinggia $2 \mathrm{M}$ diatas permukaan laut. Desa Pasir Putih kecamatan kayoa Selatan secara topografi merupakan dataran pantai dan dataran rendah. Wilayah Desa Pasir Putih yang beriklim tropis basah memiliki curah hujan sebesar 200-300 mm. Desa Pasir Putih memiliki intensitas curah hujan sedang sehingga dapat mendukung kegiatan masyarakat dalam bidang pertanian, dengan catatan di atur secara baik. Potensi dibidang kelautan, pertanian, dan industri kecil merupakan potensi unggulan yang terdapat di Desa Pasir Putih. Komoditas hasil tangkapan laut dan pertanian seperti memancing sangat menjanjikan jika dikelola dengan baik. Iklim di Desa Pasir Putih terdapat 2 musim yaitu musim hujan dan musim panas. Musim hujan terjadi pada bulan desember hingga Februari, musim panas umumnya terjadi pada bulan april sampai agustus.

Selain itu masih banyak sumber daya alam yang masih bisa digali dan dikembangkan, yang di antaranya :

1. Lahan pertanian yang masih bisa di tingkatkan produktifitasnya apabila ditunjang dengan pengelolaan yang menggunakan teknologi modern.

2. Lahan pekarangan masih belum digunakan secara maksimal sehingga dibiarkan kosong.

3. Wilayah yang merupakan perkampungan sehingga sangat potensial untuk beternak, namun belum banyak yang menyentuh.

Potensi sumber daya manusia yang ada di DesaPasir Putih masih perlu dikembangakan, berbagai tenaga terampil di bidang perikanan, pertanian, perkebunan dan informasi serta lainnya merupakan modal bagi pembangunan ekonomi dan pertanian, namun potensi ini belum bisa di maksimalkan. DesaPasir Putih dengan populasi jumlah penduduk yang cukup besar mencapai 276 jiwa merupakan potensi sumber daya manusia yang menguntungkan jika dikelola dengan baik.

Desa Pasir Putih memiliki beberapa tenaga trampil di bidang industry kerajinan sagu, pertanian dan perternakan,ahli bangunan,lainlain. Seperti sagu dan roti.

Secara ringkas potensi yang ada di DesaPasir Putih adalah sebagai berikut :

1. Sumber daya Usia produktif baik lakilaki maupun perempuan.jumlah penduduk yang besar merupakan potensi yang besar pula bagi ketersediaan tenaga kerja di DesaPasir Putih apabila diringi dengan peningkatan kualitas SDM, maka akan menjadi salah satu kekuatan pembangunan.

2. Adanya kader kesehatan posyandu dia setiap RT yang bisa menunjang peningkatan tarap kesehatan warga dan mengurangi Desa Pasir Putih kematiaan disaat melahirkan.

3. Unsur kelembagaan yang suda lengkap mulai dari perangkat Desa, BPD, LMD, PKK, Posyandu, Kelompok tani, dan nelayan.

4. Hasil pembangunan sebagai modal dasar.Hasil-hasil pembangunan baik fisik maupun non fisik yang telah dicapai oleh pemerintah Desa selama ini dapat dijadikan sebagai modal dasar sebagai tahapan pembangunan selanjutnya.

5. Adanya potensi sebagai sumber daya alam dan sumber potensi ekonomi lainnya.Potensi sumber daya alam dan potensi ekonomi yang ada di DesaPasir Putih terutama di bidang pertanian dan perikanan, yang dapat dikembangkan untuk pembangunan Desa masa kini dan masa yang akan datang,begitu juga dengan potensi sumber Daya Manusia yang ada di Desan Pasir Putih dapat mengembangkan Roda pemerintah Desa Pasir Putih kedepan yang lebih baik.

6. Budaya keterbukaan

Adanya budaya keterbukaan masayrakat Desa Pasir Putih akan menjadi bekal kejujuran serta mau menghargai pendapat pihak lain yang bersifat konstruktif

7. Rasa persaudaraan dan persamaan 
Terpeliharanya rasa persatuan dan kesatuan masayarakat DesaPasir Putih baik yang berada di daerah maupun luar daerah (merantau), menandakan masayarakat memiliki rasa nasionalisme yang tinggi. Hal ini sangat penting untuk membangun kekuatan rakyat dalam rangka mewujudkan pembangunan.

8. Kehidupan yang religious

Kehidupan religius yang sudah terbangun dalam diri masayarakat DesaPasir Putih dapat menjadi perana central dalam pembangunan, dan menjadi landasan moral dan etika dalam penyelanggaraan pemerintah maupun kemasayarakatan.

9. Ketersediaan lahan

DesaPasir Putih memiliki lahan pertanian yang subur dan cukup luas dapat digunakan untuk memajukan Desa. Untuk pengelolahannya masi perlu di optimalkan dan diolah dimanfaatkan untuk kesejahtraan masayarakat

\section{Pembangunan Ekonomi Masyarakat}

Secara umum kondisi perekonomian Desa Pasir Putih ditopang oleh beberapa mata pencaharian warga masyarakat dan dapat teridentivikasi kedalam beberapa bidang mata pencaharian, seperti: petani, nelayan, PNS, pedagang, wirausaha, pensiunan, buruh bangunan atau tukang. Adapun jumlah penduduk berdasarkan mata pencaharian dapat dilihat pada tabel berikut :

Tabel 3. Mata pencaharian

\begin{tabular}{|c|c|c|}
\hline \multicolumn{3}{|c|}{ Pekerjaan } \\
\hline Jenis Pekerjaan & Frekuensi & $\%$ \\
\hline Tidak Sekolah & 27 & 10.2 \\
\hline Sekolah & 65 & 24.6 \\
\hline $\begin{array}{c}\text { Pegawai Rumah } \\
\text { Tangga }\end{array}$ & 25 & 9.5 \\
\hline Wiraswasta/Pedagang & 12 & 4.5 \\
\hline Pelayanan Jasa & 1 &, 4 \\
\hline Petani & 5 & 1.9 \\
\hline Nelayan & 5 & 1.9 \\
\hline Buruh & 2 &, \\
\hline Lainnya Sebutkan & 18 & 6.8 \\
\hline Total & $\mathbf{2 7 6}$ & $\mathbf{1 0 0}$ \\
\hline
\end{tabular}

Tahun 2018)

(Sumber : Data Primer KKS UMMU

Berdasarkan pada tabel 3 di atas mata pencaharian terbanyak petani yang menjadi mata pencaharian unggulan di Desa Pasir Putih. Mata pencaharian terdiri dari berbagai macam bentuk yaitu : petani kopra, petani sagu, petani jagung, dan lainnya. Untuk melihat luas lahan yang dimiliki oleh masyarakat Desa Pasir Putih yaitu sebagai berikut berdasarkan tabel di bawah ini

Tabel 4. Perkembangan perekonomian

\begin{tabular}{|c|c|c|c|}
\hline \multirow[b]{2}{*}{ No } & \multirow[b]{2}{*}{ Uraian } & \multicolumn{2}{|c|}{ Jumlah } \\
\hline & & $\begin{array}{l}\text { Tahun } \\
2015\end{array}$ & Tahun 2016 \\
\hline 1 & $\begin{array}{l}\text { Luas } \\
\text { Perkebunan } \\
\text { Kelapa }\end{array}$ & $250 \mathrm{Ha}$ & $250 \mathrm{Ha}$ \\
\hline 2 & $\begin{array}{l}\text { Luas } \\
\text { Perkebunan } \\
\text { Pala }\end{array}$ & $250 \mathrm{Ha}$ & $250 \mathrm{Ha}$ \\
\hline 3 & $\begin{array}{l}\text { Luas } \\
\text { Perkebunan } \\
\text { Cengkeh }\end{array}$ & $250 \mathrm{Ha}$ & $250 \mathrm{Ha}$ \\
\hline 4 & $\begin{array}{l}\text { Produksi } \\
\text { Kelapa/Kopra }\end{array}$ & $\begin{array}{l}55 \\
\text { Ton/Tahun }\end{array}$ & $\begin{array}{l}65 \\
\text { Ton/Tahun }\end{array}$ \\
\hline 5 & Produksi Pala & $\begin{array}{l}3 \\
\text { Ton/Tahun }\end{array}$ & 3 Ton/Tahun \\
\hline 6 & $\begin{array}{l}\text { Produksi } \\
\text { Cengkeh }\end{array}$ & $\begin{array}{l}4 \\
\text { Ton/Tahun }\end{array}$ & 4 Ton/Tahun \\
\hline 7 & $\begin{array}{l}\text { Produksi } \\
\text { Kakao }\end{array}$ & $\begin{array}{l}2 \\
\text { Ton/Tahun }\end{array}$ & 2 Ton/Tahun \\
\hline 8 & $\begin{array}{l}\text { Produksi } \\
\text { Ketela/Ubi }\end{array}$ & $\begin{array}{l}4-5 \\
\text { Ton/Tahun }\end{array}$ & $\begin{array}{l}5-6 \\
\text { Ton/Tahun }\end{array}$ \\
\hline 9 & $\begin{array}{l}\text { Ternak } \\
\text { Kambing } \\
\end{array}$ & 68 Ekor & 80 Ekor \\
\hline 10 & Ternak Ayam & 68 Ekor & 80 Ekor \\
\hline
\end{tabular}

perkembangan perekonomian menjelaskan bahwa ekonomi Desa pasair putih sangat mendukung terutama pada bidang pertanian misalnya kopra, cengkeh, ketela, dan lainlainnya. Perkembangan luas pertanian dari tahun ke tahun yang paling meningkat adalah luas perkebunan kelapa dengan total penghasilan per tahun yaitu sekitar 55 ton per tahun. Sedangkan penghasilan terendah dengan produksi kakao yaitu 2 ton/tahun. Oleh karenanya, dari tabel tersebut dapat ditarik kesimpulan bahwa sebagian besar masyarakat Desa Pasir Putih mempunyai ketergatungan pada penghasilan kopra.

\section{SIMPULAN}

Berdasarkan ada hasil pengabdian yang dilakukan di Desa Pasir Putih pada Kabupaten Halmahera Selatan ada beberapa kesimpulan yang dapat dilihat yaitu sebagai berikut:

Kondisi sosial masyarakat yang dimiliki oleh masyarakat desa pasir putih masih sangat tradisional. Budaya kebersamaan dalam melakukan pekerjaaan, saling membantu antara sesama masyarakat masih sangat kuat di tengah komunitas desa.

Sumber daya alam yang dimiliki oleh masyarakat sebagain besar yaitu pertanian 
misalnya kelapa, pala serta cengkeh. Namun sumber pertanian yang menjadi penopang ekonomi masyarakat desa yaitu bertumpu pada pengelolaan sagu kering. Hasil sagu kering menjadi pengrajin andalan untuk dijual ke desa sekitar bahkan penjual sampai pasar di ternate dan bacan.

Sumber pembangunan ekonomi terbanyak petani yang menjadi mata pencaharian unggulan di Desa Pasir Putih. Mata pencaharian terdiri dari berbagai macam bentuk yaitu : petani kopra, petani sagu, petani jagung, dan lainnya.

\section{DAFTAR RUJUKAN}

Cahyono, Heru, Editor (2005) Konflik Elit Politik Pedesaan, Pustaka Pelajar dan LIPI Jakarta.

Collins, Randall (1975). Conflict Sociology, New York Academic Press.

Cathart, R.S., and Larry A. Samovar, 1974. Small Group Communication : A Reader. New York : Holt, Rinehart and Winston, Inc.

Darsono Wisadirana. (2005). Sosiologi Pedesaan. Universitas Muhamadiyah Malang : UMM Press.

Hanif Nurcholis. (2011). Pertumbuhan dan Penyelenggaraan Pemerintahan Desa. Jakarta : PT. Gelora Aksara Pratama

Hadi, A. P. (2010). Konsep Pemberdayaan, Partisipasi dan Kelembagaan Dalam Pembangunan. Yayasan

Agribisnis/Pusat Pengembangan Masyarakat Agrikarya (PPMA).

Hatu, R. (2010). PEMBERDAYAAN DAN PENDAMPINGAN SOSIAL DALAM MASYARAKAT (Suatu Kajian Teortis). Jurnal Inovasi, 7(04).

Indarti, I., \& Wardana, D. S. (2013). Metode Pemberdayaan Masyarakat Pesisir melalui Penguatan Kelembagaan di Wilayah Pesisir Kota Semarang.

Ife, J.W., (1995). Community Development: Creating Community Alternativesvision, Analysiis and Practice. Melbourne : Longman.

La Suhu, B., \& Wance, M. (2019). PEMBERDAYAAN MASYARAKAT PETANI RUMPUT LAUT DI KABUPATEN HALMAHERA SELATAN (Studi Desa Mano Kecamatan Obi Selatan). JOURNAL GOVERNMENT (Kajian Manajemen Pemerintahan dan Otonomi Daerah), 4(2), 156-172.

Miradj, S., \& Sumarno, S. (2014). Pemberdayaan masyarakat miskin, melalui proses pendidikan nonformal, upaya meningkatkan kesejahteraan sosial di Kabupaten Halmahera Barat. JPPM (Jurnal Pendidikan dan Pemberdayaan Masyarakat), 1(1), 101-112.

Muslim, A. (2007). Pendekatan Partisipatif Dalam Pemberdayaan Masyarakat. Jurnal Aplikasi IImu-ilmu Agama. Aplikasia, 8, 89-103.

Nurrani, L., \& Tabba, S. (2013). Persepsi dan tingkat ketergantungan masyarakat terhadap sumberdaya alam Taman Nasional Aketajawe Lolobata di Provinsi Maluku Utara. Jurnal Penelitian Sosial dan Ekonomi Kehutanan, 10(1).

Widjajanti, K. (2011). Model pemberdayaan masyarakat. Jurnal. Johan Galtung, "Kekerasan, Perdamaian, dan Penelitian Perdamaian", dalam Mochtar Jurnal pemberdayaan komunitas, september 2004, volum 3 ,nomor 3 , hal 171 